\title{
A teleophthalmology system for the diagnosis of ocular urgency in remote areas of Brazil
}

\author{
Um sistema de teleoftalmologia para triagem de urgências em áreas remotas do Brasil
}

\author{
Anna Giselle Ribeiro ${ }^{1}$, Renan Albert Mendonça Rodrigues², Ana Maria Guerreiro ${ }^{1}$, Caio Vinicius Saito Regatierl ${ }^{3}$
}

\begin{abstract}
Purposes: To validate a teleophthalmology mobile system aimed at improving and providing eye urgency screenings in remote and poor area settings in Brazil. The system enables one or more ophthalmologists to remotely examine a patient's condition and submit a decision describing the gravity of the case. If necessary, the patient can be forwarded to a hospital for further consultation.

Methods: A cellphone (Nexus One model, with a 5 megapixel camera) was used to collect data and pictures from 100 randomly selected patients at the Ophthalmology Emergency Room located at the General Hospital of the Federal University of São Paulo (UNIFESP). Data was then sent remotely to an online recording system to be reviewed by an ophthalmologist who provided feedback regarding the state of ocular urgency. Results were then compared to the gold standard diagnosis provided at the hospital.

Results: The diagnosis of urgency was given by two ophthalmologists: one in the hospital (gold standard) and one remotely. When we compared both diagnoses we obtained results of $81.94 \%$ specificity, $92.85 \%$ sensitivity, and $85 \%$ accuracy, with a negative predictive value of $96.72 \%$. This work also included a processing time analysis, resulting in an average time of $8.6 \mathrm{~min}$ per patient for remote consultations. Conclusions: This study is the first that has used only a cellphone for diagnosing the urgency of ocular cases. Based on our results, the system can provide a reliable distinction between urgent and non-urgent situations and can offer a viable alternative for the servicing of underprivileged areas. In screening techniques, the most important outcome is to identify urgent cases with a high level of sensitivity and predictive negative value. Thus, our results demonstrate that this tool is robust and we suggest that a major study aimed to verify its efficiency in resource-poor areas should be initiated.
\end{abstract}

Keywords: Telemedicine; Remote consultation; Ophthalmology; Diffusion of innovation; Triage; Eye diseases/diagnosis

\section{RESUMO}

Objetivos: Validar um sistema de teleoftalmologia móvel que tem como objetivo fornecer triagem de urgências oftalmológicas em áreas remotas e desfavorecidas do Brasil. O sistema permite que um ou mais oftalmologistas possam examinar remotamente a condição do paciente e apresentar uma decisão que descreve a gravidade do caso. Se necessário, o paciente será encaminhado ao hospital para consulta.

Métodos: Através de um celular e sua câmera (modelo Nexus One com câmera de 5 megapixel), foram coletados dados de 100 pacientes aleatoriamente selecionados no pronto socorro oftalmológico da Universidade Federal de São Paulo (UNIFESP) e enviados remotamente para um sistema online, por meio do qual um oftalmologista analisou-os e enviou um diagnóstico sobre a gravidade dos casos. Os resultados enviados foram comparados com o padrão ouro que foi fornecido pelo médico no hospital. Resultados: O diagnóstico foi fornecido por dois oftalmologistas: um no hospital (padrão outro) e outro remotamente. Comparando os resultados dos diagnósticos, foi obtido 81,94\% de especificidade, 92,85\% de sensibilidade, acurácia de $85 \%$ e um valor preditivo negativo de $96,72 \%$. Também foi testado o desempenho do sistema, resultando num tempo de processamento do atendimento remoto em média de 8,6 minutos por paciente.

Conclusões: Esta solução de baixo custo é a primeira da literatura que utiliza apenas o telefone celular para detectar urgências oftalmológicas. Com base nos resultados, o sistema consegue oferecer um atendimento confiável, diferenciando os casos de urgências e não urgências através da plataforma de telemedicina. Como ferramenta de triagem, o mais importante é identificar os casos de urgência (ter alta sensibilidade). Assim, os resultados obtidos demonstram que a ferramenta é robusta e traz uma possibilidade real de conduzir um estudo maior para verificar sua eficiência em áreas mais distantes e desfavorecidas.

Descritores: Telemedicina; Consulta remota; Oftalmologia; Difusão de inovações; Triagem; Oftalmopatias/diagnóstico

\section{INTRODUCTION}

The medical field is constantly searching for improved methods of diagnosis and treatment and advancements in technology have the potential to greatly assist in this quest. Although technology cannot substitute for the direct contact between physician and patient, it is increasingly becoming an essential and indispensable factor in a doctors' decision-making. Over the past several years, the role of technology in disease diagnosis and treatment in remote areas has experienced increased innovation. This has been spawned primarily by the availability of open source software, cheaper hardware including cellphone technology, and a renewed interest in alleviating the suffering of those living in poverty. Indeed, three of the eight Millennium Development Goals ${ }^{(1)}$ directly address the importance of health care in eliminating poverty.
Current telemedicine systems have addressed these issues by providing global integration and by enabling the sharing of data, images, and voices from different sources and applications ${ }^{(2,3)}$. Telemedicine is also a powerful tool for alleviating the lack of doctors in resource-poor areas. Furthermore, it is a viable option for almost all medical specialties, particularly those for which images comprise the main diagnostic tool ${ }^{(4-7)}$. Thus, the fields of radiology, dermatology, pathology, ultrasound, and ophthalmology, among others ${ }^{(8-12)}$, are especially favorable for the establishment of data transmission protocols with diagnostic purposes ${ }^{(13,14)}$

Ophthalmology, for example, can greatly benefit from telemedicine ${ }^{(15,16)}$, as it is crucial to identify patients that present urgent cases in order to avoid morbidity and permanent disorders ${ }^{(17)}$. Situations such as ocular trauma, chemical burns, corneal ulcers, orbit cellulites, retinal
Funding: No specific financial support was available for this study.

Disclosure of potential conflicts of interest: None of the authors have any potential conflicts of interest to disclose.

Corresponding author: Anna Giselle Ribeiro. Caixa Postal 1524, Natal - RN - 59078-970 - Brazil E-mail: agiselleribeiro@gmail.com

Estudo aprovado pelo Comitê de Ética em Pesquisa da Universidade Federal de São Paulo - UNIFESP/EPM. 
detachment, uveitis, arterial and venous occlusions, and acute glaucoma are examples of ophthalmologic urgencies that demand immediate care. In contrast, viral conjunctivitis, blepharitis, meibomitis, cataracts, pterygium, subconjunctival hemorrhages, and refraction errors are examples of non-urgent situations.

Thus, it is very important to differentiate between these two groups of patients. For example, preventing a patient who has acute viral conjunctivitis from travel several hours and, in contrast, a patient presenting acute glaucoma from a misdiagnoses that can result in irreversible visual impairment.

Although Brazil has more ophthalmologists than recommended by the World Health Organization (WHO) ${ }^{(18)}$ they are inadequately

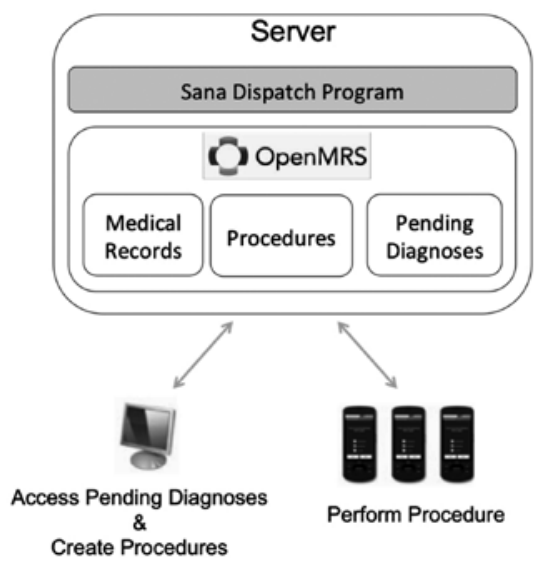

Figure 1. General overview of the Sana system. distributed, with the majority concentrated in urban areas and with rural areas being largely neglected ${ }^{(19)}$. Therefore, in order to bring ophthalmologic care to underprivileged areas, a partnership has been established between engineers and physicians from Brazil and the United States to develop a system able to perform a reliable triage for ophthalmologic urgencies.

This work presents a teleophthalmology application focused on distinguishing urgent from non-urgent ocular cases in remote areas, in order to forward only urgent cases to a hospital. The tool was developed to be used by any health professional, as it requires little expertise to manipulate its clinical application.

\section{METHODS}

Following ethics committee approval, data were collected using a cellphone and its camera. This data was obtained from 100 patients (48 men and 52 women, mean age of 35.9 years) randomly selected from the Ophthalmology Emergency Room, Sao Paulo Hospital. All the information was sent to the server through a mobile solution based on the Sana platform ${ }^{(20)}$, which is able to capture patient's data and pictures through a mobile application called Procedure.

The mHealth Sana platform (Figure 1) consists of a remote Android client application ${ }^{(21)}$, a custom mobile dispatch program (SDP) implemented on Django and Python ${ }^{(22,23)}$, and a backend electronic medical record system such as OpenMRS ${ }^{(24,25)}$. This framework allows for an easily customizable front-end interface, and the reception and transmission of clinical data is reliable even on a network with weak connectivity.

The procedure comprised a questionnaire (Figure 2) that covered the main questions asked by a doctor in a face-to-face triage system. These included eye signs (redness, secretion, glued eye, pupil

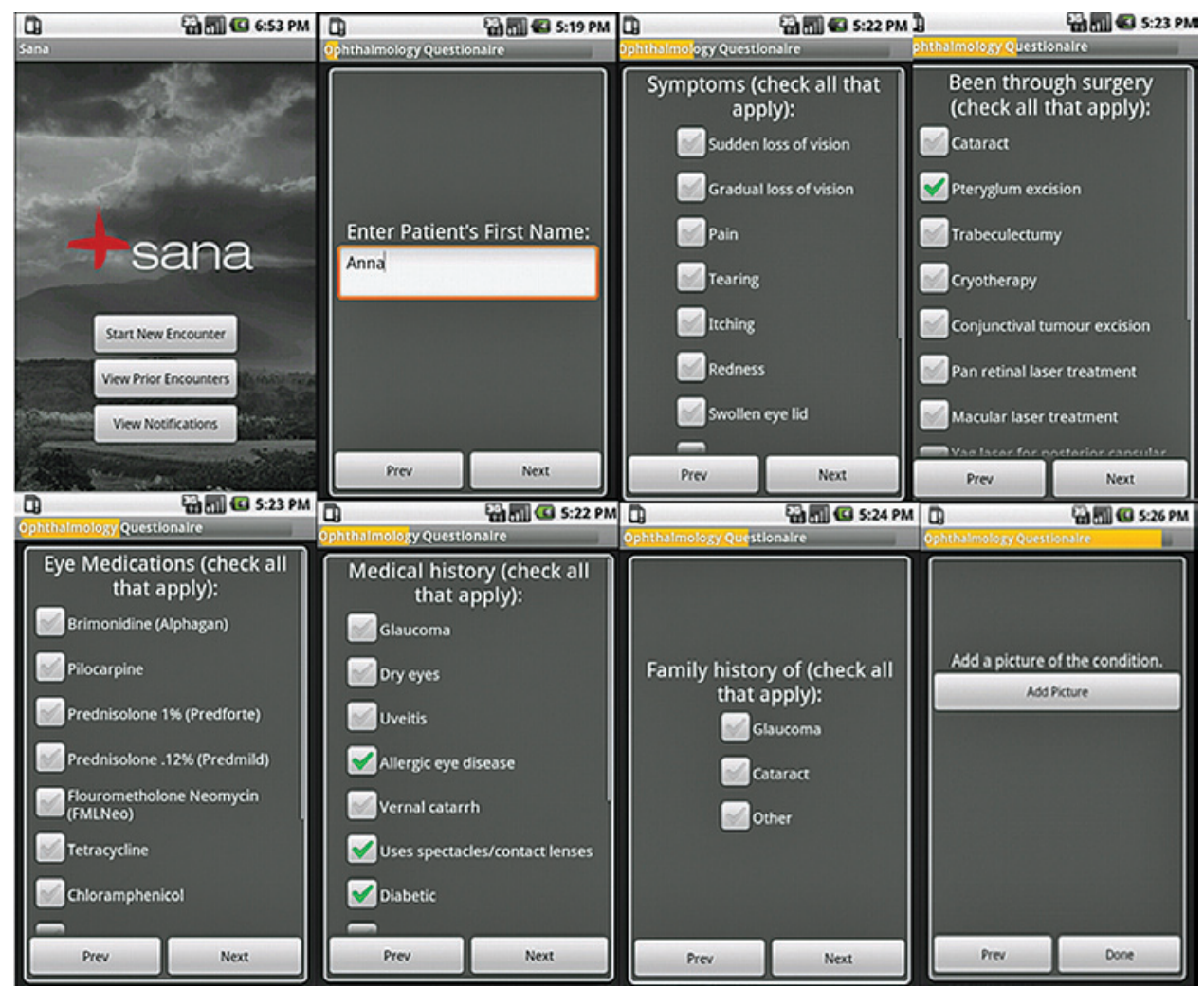

Figure 2. Some pages of the ophthalmology Sana procedure. The questionnaire contains five standard questions (patient ID, first name, last name, age, gender) and 18 specific questions divided into branches that change according to the previous answer. It also allows for the acquisition of two images (right eye, left eye). 
color), eye symptoms (pain, itching, vision loss, burns, tearing, light sensibility, diplopia), and a history of unusual events (trauma, surgery, chemical contact, chronic diseases, eye drops). It also involved the attachment of images of the eye using the cellphone camera module (Figures 3 and 4) with a special lens (+60 D) coupled to the cellphone camera for improved images of the anterior segment. The application collected and saved data from the questionnaire and sends it to a server via a secure wireless Sana Mobile platform. It was then analyzed by

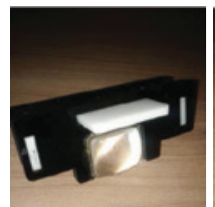

A
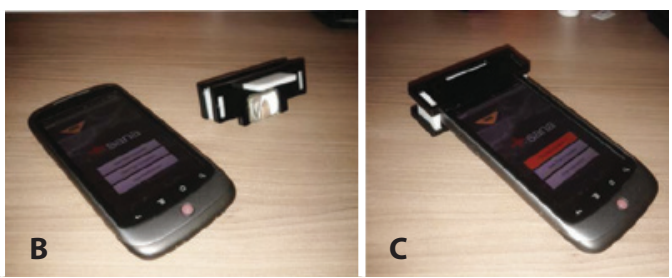

Figure 3. Cell phone carrying Sana mobile System and the lens adapter used for data acquisition.
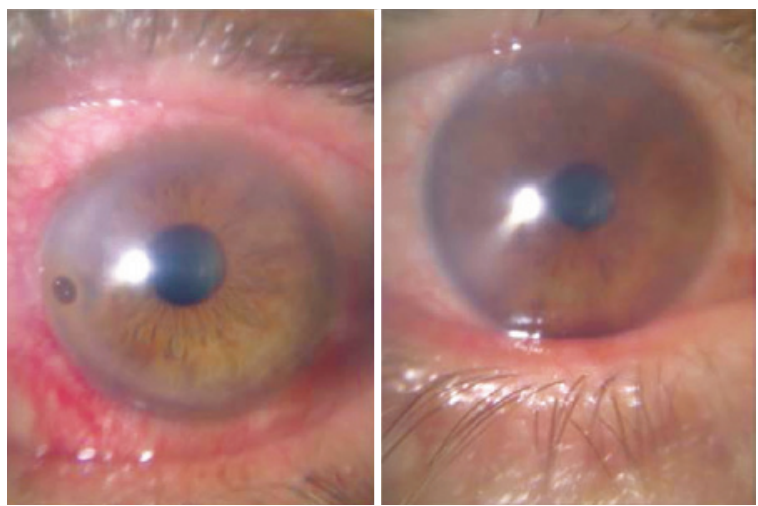

Figure 4. Patients diagnosed with a corneal foreign body (urgency) and blepharitis (non-urgency). an ophthalmologist (Figure 5) who was responsible for providing feedback regarding the patients' diagnosis (Figure 6). The physician was able to access the patient's medical history, including their location, current and previous medication, previous medical procedures, etc. The diagnosis of the physician, was sent back to the phone via email or Short Message Service (SMS), with the cellular network operators being responsible for delivering an SMS notification as soon as the phone re-entered the service area.

Although the absence of biomicroscopy can hamper the diagnosis of diseases such as uveitis, this system is able to combine the questionnaire and the photos of the anterior segment to track signs and symptoms of ocular urgency. In cases that suggest likely visual loss the patient can subsequently be rapidly referred for further ophthalmologic evaluation.

\section{RESULTS}

Urgencies were defined as all cases that required an immediate medical intervention in the emergency room, for diagnostic approach, necessity of ancillary exams or surgical procedures.

The results of this study were obtained by comparing the diagnoses (classified as either urgent or non-urgent) provided by the local (gold standard) and the remote ophthalmologists. The diagnoses provided at the hospital were first provided by a resident ophthalmologist and were then confirmed by the head of the sector. The remote feedback was given by a physician (and PhD) with over six years of ophthalmology experience.

As seen in table 1, the sensitivity and specifity in detecting urgent cases were $92.85 \%$. and $81.94 \%$, respectively. This results in an accuracy of $85 \%$, a positive predictive value of $66.66 \%$, and a negative predictive value of $96.72 \%$. Most serious cases were identified and few false positives were recorded, thus resulting in the observed high sensitivity value ${ }^{(26-28)}$. These results indicate that this screening system works extremely well.

The two urgent cases that were not detected were a case of ocular toxoplasmosis, in which the patient did not complain of visual impairment, and a case of phlyctenula which required antibiotic/ corticosteroid topical treatment.

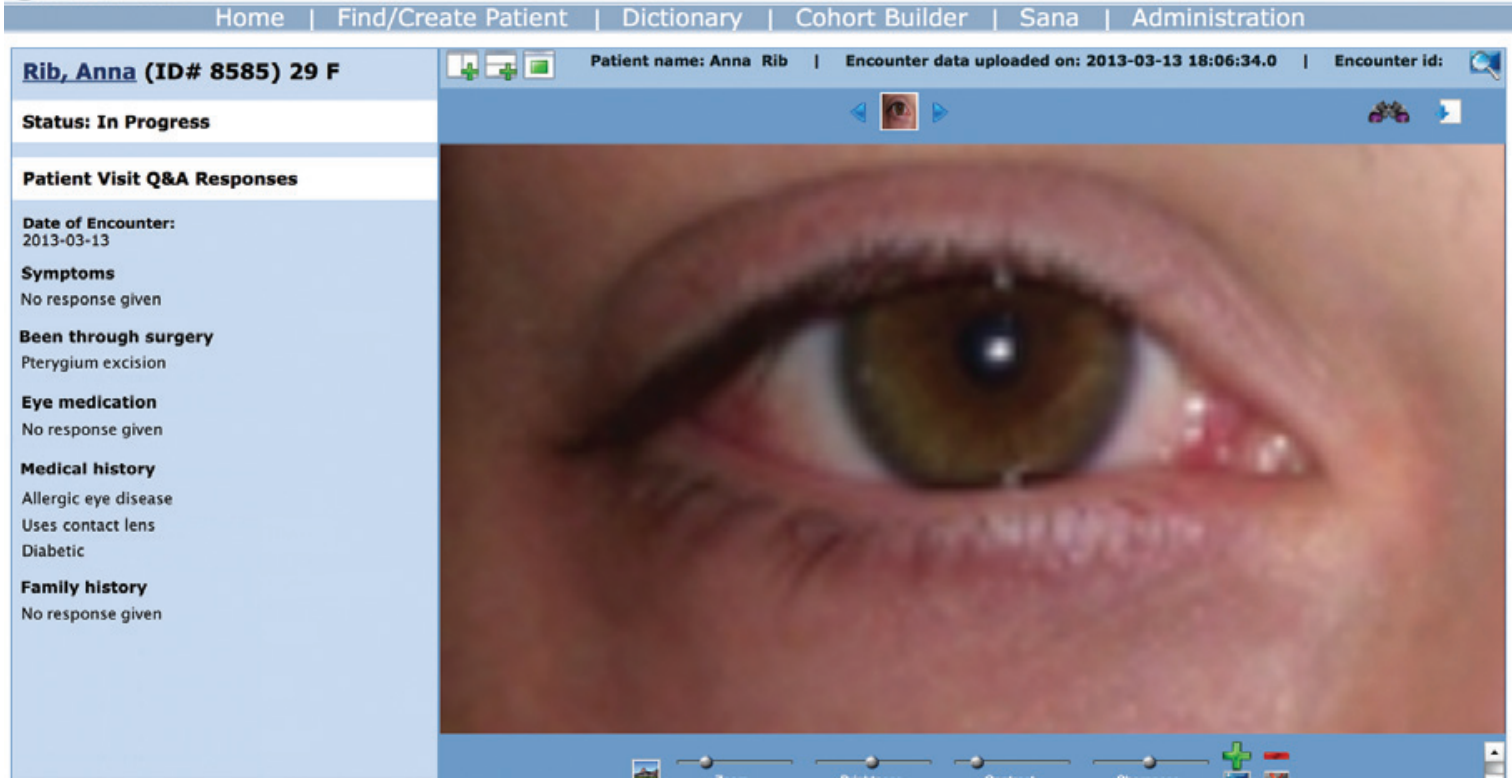

Figure 5. OpenMRS doctor module where a physician accesses the patient data and provides feedback with diagnose and recommendations. 


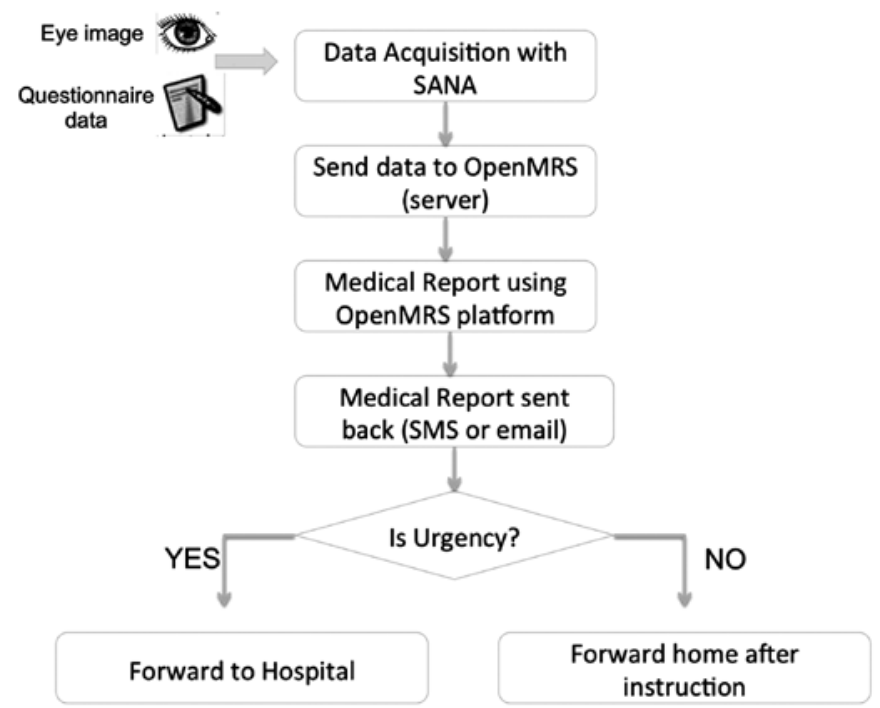

Figure 6. System flow chart demonstrating data flow and how the system works from the initial data acquisition to a final decision regarding urgency.

Table 1. Trial results for statistics analysis

\begin{tabular}{lccc}
\hline \multicolumn{4}{c}{ Case is it urgency? } \\
\hline Onsite vs. offsite diagnose & Urgency & Non-urgency & Total \\
Urgency & 26 (true positive) & 13 (false positive) & 39 (positive tests) \\
Non-urgency & 2 (false negative) & 59 (true negative) & 61 (negative tests) \\
Total & 28 urgencies & 72 non-urgencies & 100 patients \\
\hline
\end{tabular}

\section{Remote diagnose}

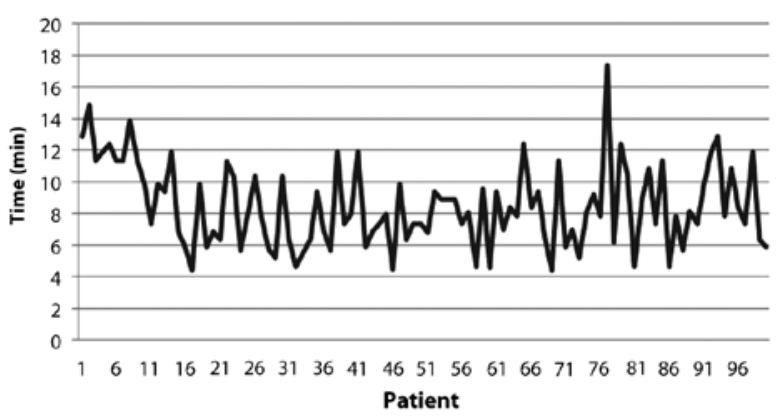

Figure 7. Time spent to complete the remote diagnose, including consultation, transmission, and evaluation times. The average time taken per patient was $8.6 \mathrm{~min}$.

The system performance and data transmission times were also analyzed, as low data transmission rates are known to be an important issue in resource poor areas ${ }^{(29,30)}$. However, Brazil has a very favorable geography for data transmission and even remote areas have good cellphone coverage. Given this scenario, some tests were performed to validate the system's transmission rates. These tests were performed assuming a low speed network coverage such as a $2 \mathrm{G}$ connection.

Time required to perform the questionnaire. The questionnaire contained five standard questions (patient ID, first name, last name, age, gender) and 18 specific questions. The answers to these questions form a flow diagram that divides into branches. Images of the left and right eyes are included in the diagram (Figure 2). The data collection times take into consideration all time spent in completing the questionnaire. Our results indicated that the questionnaire took an average of $5.2 \mathrm{~min} /$ patient.

Time required for data transmission. Occasionally the initial transmission attempt failed. However, the system is designed to continue to re-send the information until the data transmission is successful. Our results indicated that the average time for successfully uploading the data for one patient was $1.9 \mathrm{~min}$.

Time required for data analysis. The physician had been previously trained to use the application software, which is very simple to manage. For diagnosis, each image could be zoomed in or out for further viewing. The average diagnosis time for each subject, including feedback data entry, was approximately $1.5 \mathrm{~min}$.

Figure 7 shows the average time taken for a remote consultation, including applying the questionnaire, transmitting the data, and performing the analysis. The standard deviation was found to be $2.62 \mathrm{~min}$.

\section{DISCUSSION}

Health systems face multiple challenges worldwide, including personnel shortages, financial pressures, and an increasing proportion of the population with chronic medical conditions. This paper presents an innovative teleophthalmology solution for ophthalmology triage. It is not intended that teleophthalmology will replace face-to-face ophthalmic consultations. However, electronic systems can assist physicians and their patients by reducing the waiting time, preventing unnecessary travel to a consultant's surgery, and increasing the geographical area assisted. Furthermore, being a low-cost 
and low-power solution, the system can efficiently decrease costs to health care systems.

This is an innovative project as all similar previously reported studies have used refractive tests, slit-lamps, or other examinations that are difficult to perform in rural areas due to a lack of equipment. To our knowledge, this system is the first one to use only a cellphone for ophthalmologic urgency detection. Based on the information acquired and the physician support, the system is capable of accurately distinguishing between urgent and non-urgent cases through its telemedicine platform.

One difficulty detected during this process related to image acquisition, where a patient's orbit and eye anatomy could sometimes compromise the picture's quality. Notably, if an error is made by the operator whilst using the application, it is possible to go back/ forward to the previous or next screen. Following its collection, all data are auto-saved and the program will wait until it detects an available Internet connection to send all data to the server.

Our results demonstrate a high sensitivity (92.85\%) and negative predictive value (96.72\%), along with a fast data transmission time (average $1.9 \mathrm{~min}$ ). Thus, we have shown that the tool is very robust and that a major additional study is warranted, aimed at verifying its efficiency in resource-poor areas. It is important to emphasize that the system works better at detecting anterior segment diseases, but by combining information from the questionnaire with ocular images we aim to at least be able to identify urgent cases that require ancillary exams, even if they involve posterior segment diseases.

\section{ACKNOWLEDGMENTS}

We wish to acknowledge the National Council for Scientific and Technological Development (CNPq - Brazil), Federal University of Rio Grande do Norte, Massachusetts Institute of Technology and Federal University of São Paulo.

\section{REFERENCES}

1. Wallace S, Wyatt J, Taylor P. Telemedicine in the NHS for the millennium and beyond. Postgrad Med J. 1998;74(878):721-8.

2. Maceratini R, Sabattini RM. Telemedicina: a nova revolução. Rev Informédica. 1994; 1(6):5-9.

3. Murthy GV, Gupta SK, Bachani D, Tewari HK, John N. Human resources and infrastructure for eye care in India: current status. Natl Med J India. 2004;17(3):128-34.

4. Weinberg DS, Allaert FA, Dussere P, Drouot F, Retailliau B, Welch WR, et al. Telepathology diagnosis by means of digital still images: an international validation study. Hum Pathol. 1996;27(2):111-8. Comment in: Hum Pathol. 1996;27(2):99-101.

5. Chao LW, Cestari TF, Bakos L, Oliveira MR, Miot HA, Zampese GM, et al. Evaluation of an Internet-based teledermatology system. J Telemed Telecare. 2003;9(1):S9-12.

6. Weinstein $\mathrm{MH}$, Epstein $\mathrm{Jl}$. Telepathology diagnosis of prostate needle biopsies. Hum Pathol. 1997:28(1):22-9.
7. Singson RP, Natarajan S, Greenson JK, Marchevsky AM. Virtual microscopy and the Internet as telepathology consultation tools. A study of gastrointestinal biopsy specimen. Am J Clin Pathol. 1999;111(6):729-5. Comment in: Am J Clin Pathol. 2000;113(4):595.

8. Parasyn A, Hanson RM, Peat JK, Silva M. A comparison between digital images viewed on a picture archiving and communication system diagnostic workstation and on a PC-based remote viewing system by emergency physicians. J Digit Imaging. 1998; 11(1):45-9.

9. Eng J, Mysko WK, Weller GE, Renard R, Gitlin JN, Bluemke DA, et al. Interpretation of emergency department radiographs: a comparison of emergency medicine physicians with radiologists, residents with faculty, and film with digital display. Am J Radiol. 2000;175(5):1233-8. Comment in: AJR Am J Roentgenol. 2000;175(5):1213.

10. Perednia DA, Gaines JA, Rossum AC. Variability in physician assessment of lesions in cutaneous images and its implications for skin screening and computer - assisted diagnosis. Arch Dermatol. 1992;128(3):257-64. Comment in: Arch Dermatol. 1992; 128(3):390-3.

11. Barnard CM, Goldyne ME. Evaluation of an asynchronous teleconsultation system for diagnosis of skin cancer and other skin disease. Telemed J. 2000;6(4):379-83.

12. Loane MA, Bloomer SE, Corbett R, Eedy DJ, Hicks N, Lotery C, et al. A comparison of real- time and store-and-forward teledermatology: a cost-benefit study. $\mathrm{Br} J \mathrm{Derma-}$ tol. 2000;14(6)3:1241-7.

13. Stanberry B. Telemedicine: barriers and opportunities in the $21^{\text {st }}$ century. J Intern Med. 2000;247(6):615-28.

14. Krupinski E, Nypaver M, Poropatich R, Ellis D, Safwat R, Sapci H. Clinical applications in telemedicine/telehealth. Telemed J E Health. 2002;8(1):13-34.

15. Li HK. Telemedicine and ophthalmology. Surv Ophthalmol. 1999;44(1):61-72.

16. Lamminen $H$, Salminen $L$, Uusitalo $H$. Teleconsultations between general practioners and ophthalmologists in Finland. J Telemed Telecare. 1999;5(2):118-21.

17. Ilyas S. Eye Diseases. Jakarta: Balai Penerbit FKUI; 2005.

18. World Health Organization. Telemedicine:opportunities and developments in Member States [Internet]. Geneva:WHO; 2009. [cited 2012 Jun 21]. Available from: http:// www.who.int/goe/publications/goe_telemedicine_2010.pdf

19. Conselho Brasileiro de Oftalmologia. Censo Oftalmológico. São Paulo: Conselho Brasileiro de Oftalmologia; 2012.

20. Center for Health Marked Innovations. Sana Mobile[Internet].[cited 2012 Mar 19]. Available from: http://healthmarketinnovations.org/program/sana-mobile

21. Android Mobile OS [Internet]. [cited 2012 Jun 21]. Available: http://www.android.com

22. Python Programming Language [Internet]. [cited 2013 Jan 21]. Available from: http:// www.python.org

23. Django Web Framework [Internet] [cited 2013 Jun 21]. Available from: http://www djangoproject.com

24. OpenMRS Medical Record System. [Internet]. [cited 2013 Nov 21]. Available: http:// openmrs.org

25. Mamlin BW, Biondich PG, Wolfe BA, Fraser HS, Jazayeri D, Allen C, et al. The OpenMRS System: Collaborating Toward an Open Source EMR for Developing Countries. In: Proceedings of the AMIA Annual Symposiu, 206. p.529-33.

26. Fleiss JL. Statistical methods for rates and proportions. $2^{\text {nd }}$ ed. New York: Wiley; 1981.

27. Galen RS, Gambino SR. Beyond normality: the predictive value and efficiency of medical diagnosis. New York: Wiley \& Sons; 1975

28. Vecchio TJ. Predictive value of a single diagnostic test in unselected populations. N Engl J Med. 1963;274(21):1171-3.

29. Loane M, Wootton R. A review of guidelines and standards for telemedicine. J Telemed Telecare. 2002;8(2):63-71.

30. Roine R, Ohinmaa A, Hailey D. Assessing telemedicine: a systematic review of the literature. CMAJ. 2001;165(6):765-71. Comment in: CMAJ. 2001;165(6):777-9. 